Є. В. Любий ${ }^{1}$, В. М.Чижик ${ }^{1}$, С. В. Ковбан ${ }^{2}$

${ }^{1}$ Харківський національний автомобільно-дорожній університет, Харків, Україна

${ }^{2}$ Одеський національний політехнічний університет, Одеса, Україна

\title{
ДОСЛІДЖЕННЯ ЯКОСТІ ОБСЛУГОВУВАННЯ ПАСАЖИРІВ НА АВТОБУСНОМУ МАРШРУТІ №240 МІСТА ОДЕСИ
}

\begin{abstract}
Предметом вивчення в статті $є$ якість транспортного обслуговування пасажирів на автобусному маршруті №240 в місті Одесі. Метою дослідження $є$ проведення оцінки якості транспортного обслуговування пасажирів на автобусному маршруті №240 в місті Одесі, основною вихідною базою якої є результати натурних спостережень за роботою автобусів на маршруті, і вибір заходів, спрямованих на підвищення ефективності функціонування маршруту. Завдання дослідження: аналіз існуючих підходів оцінки якості транспортного обслуговування пасажирів громадським транспортом; вибір і обгрунтування підходів вивчення попиту на пересування пасажирів громадським транспортом; розробка методики проведення натурних обстежень роботи автобусів на маршруті; визначення обраних параметрів якості транспортного обслуговування пасажирів; розробка заходів щодо підвищення якості транспортного обслуговування пасажирів на маршруті №240. Отримані наступні результати: проаналізовані основні підходи оцінки якості транспортного обслуговування пасажирів громадським транспортом, а також нормативноправову базу в цій сфері; розроблена методика і наведені результати натурних обстежень роботи автобусів на маршруті; розраховані основні параметри якості транспортного обслуговування пасажирів на маршруті (середня дальність поїздки, коефіцієнт нерівномірності пасажиропотоків, коефіцієнт динамічного використання місткості автобуса, коефіцієнт змінюваності, транспортну роботу, регулярність руху, час очікування), на підставі яких запропоновано заходи щодо підвищення ефективності роботи маршруту. Висновки. Розроблена методика проведення натурних обстежень якості обслуговування пасажирів дає можливість отримати вихідні дані для подальшого визначення і розрахунку параметрів якості обслуговування на маршруті: регулярність руху автобусів, ступінь використання місткості транспортного засобу, середня дальність поїздки пасажирів, коефіцієнт змінності, коефіцієнт нерівномірності пасажиропотоків, час очікування на зупиночному пункті. Для підвищення якості обслуговування пасажирів на маршруті пропонується зменшити інтервал руху автобусів до 9 хв., Що призведе до необхідності придбання двох додаткових автобусів місткістю 50-60 пас.
\end{abstract}

Ключов і слов а : громадський транспорт, маршрут, натурні спостереження, пасажиропотік, якість транспортного обслуговування.

\section{Вступ}

Одним із основних факторів, що характеризують діяльність будь-якої фірми, є якість ії продукції чи послуг. На ринку транспортних послуг спостерігається тенденція постійно зростаючих вимог з боку споживачів до більш високого рівня якості. Тому, щоб досягти стійкого функціонування економіки країни необхідно постійно підвищувати якість наданих послуг.

Процес виробництва і споживання транспортної послуги співпадає в часі та просторі. Продукція транспорту виготовляється та споживаються одночасно. Тому індивідуальні витрати транспорту на конкретному напрямі можуть розглядатись як суспільно-необхідні витрати праці на транспортування продукції за суспільно-нормативних умов виробництва. Виробничі відносини конкретизуються в середині міжгалузевого комплексу з виробництва та надання споживачеві кінцевого продукту - перевезення. Таким чином, якість виражає кінцевий результат діяльності такого комплексу, і кінцева якість залежна від роботи на кожному етапі транспортного виробництва [1].

До основних факторів якості перевезення пасажирів відноситься: комфортність поїздки (наповнення транспортних засобів (ТЗ) та регулярність їх руху на маршрутах), час на пересування пасажирів, безпека перевезень. Умови, що визначають ці фактори, наступні: щільність маршрутної мережі, частота та точність руху міського транспорту, швидкість сполу- чення, стан інформації та реклами про роботу пасажирського транспорту, інформування пасажирів про маршрут та інтервал рух Т3, гігієнічний та естетичній стан ТЗ, облаштування та оформлення зупиночного пункту та кваліфікація персоналу.

Оцінка якості пасажирських перевезень проводиться для того, щоб можна було визначити та здійснити уточнення вимог щодо якості перевезень на основі систематичного вивчення росту вимог до якості, розробити організаційно-технічні заходи щодо удосконалення транспортного виробництва 3 метою досягнення установлених нормативів якості, забезпечити отримання оперативної інформації щодо ефективності та якості транспортного обслуговування, а також аналіз цієї інформації для виявлення відхилень від нормативів та усунення причин, які їх викликають та ін.

Розглядаючи концепцію розвитку міського транспорту, в першу чергу, можна виділити проблему якості обслуговування пасажирів. Для того щоб громадський транспорт використовувався частіше i якісніше, він повинен не втратити свої головні переваги: швидкість, комфорт, доступність. У цьому полягає суть проблеми якості обслуговування пасажирів міським транспортом. Слід також розуміти, що одним з основних завдань організації руху міського транспорту є забезпечення найбільш високої якості пасажирських перевезень при мінімальній собівартості перевезення. Підвищення якісних показників транспортного обслуговування призводить до зростання собівартості пасажирських перевезень. Тому вимога максимізації якісних показників пасажирсь- 
ких перевезень і мінімізації їх собівартості суперечать один одному. Якщо до того ж врахувати нерегульовані випадкові коливання пасажиропотоків у часі і по довжині транспортної мережі, неминучі затримки руху маршрутного пасажирського транспорту при роботі в загальному потоці вуличного руху, то можна зазначити, що складання оптимального плану руху являє собою досить складну задачу.

\section{Сучасні умови контролю та нормування якості перевезення пасажирів}

Діяльність з надання пасажирських автотранспортних послуг в Україні регламентується законодавчою та нормативною базами [2-7].

Закон України «Про дорожній рух» [4] визначає правові й соціальні основи дорожнього руху з метою захисту життя та здоров'я громадян, а також регламентує безпечні й комфортні умови для учасників руху. Закон України «Про автомобільний транспорт» [2] визначає принципи організації та експлуатації автомобільного транспорту. У даному законі йдеться про необхідність забезпечення надання доступних послуг на достатньому рівні якості, забезпечення виконання вимог щодо технічного обслуговування і ремонту ТЗ. У постанові [3] визначається порядок здійснення міських, приміських, міжміських і міжнародних перевезень пасажирів, багажу, ручної поклажі й посилок, перевезень організованих груп дітей і туристів, обслуговування громадян на автостанціях і автовокзалах. У [5-7] представлено основні положення щодо технічного обслуговування, ремонту автомобільних Т3, робочого часу водіїв, положення щодо їх медичного огляду. Національний стандарт [7] установлює експлуатаційні вимоги й методи контролю технічного стану ТЗ.

Підвищення якості та конкурентоспроможності товарів (процесів, робіт, послуг) можливе тільки на основі стандартизації. Вона дозволяє регламентувати вимоги до якості продукції, більш ефективно вирішувати проблеми спеціалізації, визначати раціональні способи виробництва продукції і переробки сировини, здійснювати управління якістю товарів у виробництві та сфері обігу [8].

Відповідно до стандарту (ДСТУ ISO 90002001) якість - це міра, в якій сукупність власних характеристик задовольняє вимоги.

Серія стандартів ISO 9000 включає кілька стандартів систем забезпечення якості. Дані стандарти розробляються Міжнародною Організацією зі Стандартизації (ISO) і мають той самий зміст, що і відповідні європейські стандарти (EN), а також національні стандарти в ряді країн. Серію стандартів ISO 9000 складають моделі або керівні вказівки. Всі ці документи називаються стандартами, незважаючи на те, що деякі з них є посібниками чи збірниками рекомендацій. Серія стандартів ISO 9000 являє собою узагальнення національних і міжнародних стандартів 3 системи якості. Стандарти ISO 9000 визнані практично у всьому світі і прийняті в якості національних стандартів більш ніж в 70 країнах. Ці стандарти дуже популярні в країнах, які проводять активну міжнародну торгівлю, таких як США, Ка- нада і Японія, а також в країнах ЄС. Першим стандартом систем якості був американський стандарт US Mil Spec (Mil-Q-9 858), опублікований в 1959 році. Розроблені з того часу різні стандарти систем якості мають багато спільних властивостей.

Нова редакція стандартів серії ISO 9000 зазнала суттєвих змін і заснована на концепції бізнеспроцесів, а також включає в себе деякі нові області процес безперервного вдосконалення, оцінку задоволеності замовника випущеною продукцією або наданими послугами, менеджмент ресурсів. Стандарт ISO 9000:2001 визначає систему якості як «сукупність організаційної структури, процедур, процесів і ресурсів, необхідних для здійснення адміністративного управління якістю».

15 листопада 2008 року Міжнародною Організацією зі Стандартизації опублікована нова версія міжнародного стандарту ISO 9001. ISO 9001:2008 замінює стандарт ISO 9001:2000, застосовуваний як до комерційних, так і до громадських організацій в 170 країнах. У новій версії стандарту: не міститься нових вимог; додані роз'яснення до існуючих вимог; зміни носять головним чином редакційний характер; внесено кілька змін, спрямованих на підвищення сумісності з ISO 14001:2004. Описані в цьому стандарті вимоги до систем менеджменту якості доповнюють вимоги до продукції. Цей стандарт використовується самою організацією або зовнішньою стороною (споживачами, органами з сертифікації) для регламентації власних вимог організації і оцінювання іiі здатності задовольняти потреби споживача.

В свою чергу, сертифікація послуг автомобільного транспорту проводиться відповідно до «Переліку продукції, що підлягає обов'язковій сертифікації в Україні», затверджених наказом Держспоживстандартом України від 01.02.2005 р. № 28 [9], а також «Правил обов'язкової сертифікації послуг автомобільного транспорту», затверджених наказом Державного комітету України по стандартизації, метрології та сертифікації та Міністерством транспорту України від 19.03.99 р. № 119/156 [10].

Правила сертифікації послуг автомобільного транспорту встановлюють порядок і вимоги щодо проведення сертифікації послуг автомобільного транспорту в Українській державній системі сертифікації продукції, процесів та послуг - Системі сертифікації УкрСЕПРО. Правила є обов'язковими для органів із сертифікації послуг автомобільного транспорту (ОС), а також підприємств, установ, організацій та громадян - суб'єктів господарювання, які надають послуги автомобільного транспорту, незалежно від форм власності [10].

Сертифікацію послуг автотранспорту у Системі УкрСЕПРО проводять ОС, що акредитовані в установленому законом порядку. Організаційно-методичним $\epsilon$ Державний автотранспортний науководослідний i проектний інститут (ДержавтотрансНДІпроект). Сертифікація послуг проводиться на їх відповідність вимогам нормативних документів щодо безпеки життя, здоров'я людей, захисту їх майна та охорони довкілля. Порядок сертифікації послуг автомобільного транспорту передбачає: 

до неї;

- подачу заявки на сертифікацію та документів

- розгляд заявки та документів;

- прийняття рішення за заявкою на проведення сертифікації послуг;

- укладення договору на проведення сертифікації;

- обстеження виробництва перевізника;

- перевірку (випробування) дорожніх Т3 на відповідність вимогам певного виду послуг;

- видачу сертифіката відповідності;

- технічний нагляд за наданням послуг.

Перевізник може одержати сертифікат відповідності на послуги лише за наявності в нього умов для забезпечення вимог нормативних документів, на відповідність яким проводиться сертифікація, а саме:

- забезпечення нормативною і технічною документацією, що встановлює вимоги щодо безпеки перевезення пасажирів;

- забезпечення належними ТЗ відповідного технічного стану;

- забезпечення медичного контролю та інструктажу водіїв;

- належного кваліфікаційного рівня $з$ питань безпеки перевезень перевізників, водіїв та осіб, діяльність яких пов'язана 3 наданням транспортних послуг.

Оцінка перевізника щодо надання послуг проводиться згідно з вимогами Правил надання послуг пасажирського автомобільного транспорту. Установлюються відповідність фактичного стану надання послуг вимогам нормативної документації та можливість перевізника надавати послуги у відповідності з їі вимогами. За результатами оцінки перевізника щодо надання послуг визначаються періодичність та обсяг проведення технічного нагляду за наданням сертифікованих послуг. Слід також зазначити, що якість послуг як продукту діяльності підприємства, $\epsilon$ та, що лише становить якість усього підприємства. Послуги є реалізацією його виробничої функції. Окрім неї у підприємства існують інші функції, які забезпечують нормальну роботу підприємства, такі як комерційна, адміністративна, постачання, облік, безпека, фінанси, управління ресурсами тощо. Підприємство працює якісно, якщо забезпечується якість реалізації всіх функцій підприємства.

\section{Аналіз публікацій}

Показники якості транспортних послуг залежно від методу їх визначення можна розділити на дві групи - розрахункові та експертні показники [11].

До групи розрахункових показників належать показники якості, які можна оцінити кількісно (наприклад, термін виконання послуги).

В свою чергу, до експертних показників належать більшість показників якості (культура обслуговування, інформативність та ін.), що не піддаються кількісній оцінці. Їх можна оцінити тільки експертним шляхом. Порівняння розрахункових показників зробити легше, ніж експертних показників, оскільки оцінити їх можна тільки експертним методом. Водночас багато якісних характеристик, суб'єктивно оцінених клієнтами, можуть бути піддані кількісному виміру самою транспортною організацією за наявності розробленої методики їх оцінки.

Якість обслуговування на транспорті оцінюється за такими параметрами [12]:

- якістю основної послуги (перевезення, логістика, оренда);

- якістю подальшого обслуговуванням;

- інформаційним обслуговування;

- дотриманням графіку перевезень;

- компетентністю і професіоналізмом персоналу.

Якість пасажирських перевезень можна оцінити по відношенню накладних витрат часу (сума часу підходу пасажира до зупиночного пункту, часу очікування посадки та часу проходження від зупиночного пункту до мети поїздки) до часу поїздки, а також сумі часу очікування посадки та часу поїздки. Можливість економії часу закладено в скороченні цих елементів, особливо часу очікування посадки. Сума часу підходу до зупиночного пункту і очікування дає оцінку раціональності і точності руху транспорту. В цьому випадку для підвищення якості $\epsilon$ два шляхи: перший - зменшення часу підходу шляхом розвитку мережі і другий - знизити час очікування за рахунок збільшення інтенсивності (скорочення інтервалу руху Т3) [13].

Реалізація функцій управління забезпечує контролювання, регулювання та координацію роботи рухомого складу при виконанні планів перевезень пасажирів в умовах численних зовнішніх і внутрішніх факторів нестійкості.

Особлива роль в ефективній роботі міського пасажирського транспорту належить управлінню технологічними процесами. Для ефективного функціонування ринку транспортних послуг першочергове значення має повна інформація про попит на них, тобто про транспортні потреби жителів міста. Єдиним джерелом інформації, який характеризує параметри транспортного попиту та умови його задоволення в існуючій транспортній системі, є методи дослідження пасажиропотоків [14].

Методи дослідження класифікуються за рядом ознак [14]:

- за тривалістю охоплюваного періоду: систематичні (щодня, щотижня і т.д.), разові (короткочасні).

- по ширині охоплення: суцільні (одночасно по всій транспортної мережі котрий обслуговується району) в середньому 1 раз на 3 роки; вибіркові (по окремих районах руху) 1 раз в квартал.

- по виду:

a) анкетний метод (шляхом заповнення попередньо розроблених спеціальних опитувальних анкет);

б) звітно-статистичний метод грунтується на квитково-облікових листах i кількості проданих квитках;

в) талонний метод (шляхом видачі обліковцям спеціально заготовлених талонів різних кольорів);

г) табличний метод (проводиться обліковцями розташованими всередині автобуса біля кожних дверей, шляхом заповнення заздалегідь заготовлених таблиць); 
д) візуальний або окомірний метод (проводиться візуально за бальною системою від 1 до 6 балів), їм можуть користуватися водії чи кондуктора;

е) силуетний метод - різновид візуального (за 5-ти бальною системою, шляхом набору силуетів за типами автобусів);

ж) опитувальний метод - шляхом опитування обліковцем в салоні пасажирів, цей метод дозволяє визначити дані про кореспонденцію пасажирів;

к) автоматизований метод - підрахунок пасажирів виконується за допомогою спеціальних приладів.

Також для оцінки якості використовуються засоби порівняння фактичного значення показника 3 нормативним [15]. Далі виявляються розбіжності даних значень і встановлюються причини останнього. В основі процедури оцінки якості обслуговування пасажирів закладений комплексний підхід, який носить рекомендаційний, декларативний характер, тому якість важко виміряти. У зв'язку з цим при визначенні процедур комплексного підходу рекомендується виділити наступні показники якості транспортного обслуговування пасажирів: доступність (щільність маршрутної мережі, рівень інформаційного забезпечення пасажирів, стабільність тарифів); результативність (рівень транспортної втоми, час на пересування); надійність (регулярність руху, кількість відмов у посадці, безпека); зручність (коефіцієнт заповнення салону Т3, комфортабельність) [15].

Нормативом показника якості є значення показника, що відповідає межі різних оцінок якості. Нормативи слід розділити на граничні і шкальні. Граничні нормативи показників якості розмежовують об'єкти на два типи за принципом «придатнийнепридатний». Шкальні нормативи показників якості встановлюють значення показників, які відповідають різним оцінками (за принципом бальної оцінки: незадовільно, задовільно, добре, відмінно і т. ін.). Загальні вимоги до показників якості виражаються таким чином, щоб відобразити реальні інтереси пасажирів і суспільства [16].

Оцінку якості транспортних послуг компанії, дану клієнтом, багато фахівців називають єдиною посправжньому об'єктивною. Адже компанія працює саме для споживача кінцевої послуги. А тому саме клієнт виносить остаточний вердикт про якість обслуговування на транспорті. До чинників, що визначають якість послуги очима клієнта, належать такі: виконання роботи відповідно до вимог нормативних документів; міра доступності послуги; репутація підприємства; інформація про продукт і фірму; надійність; безпека; компетентність персоналу; можливості і рівень спілкування; реакція і поведінка персоналу; зовнішній вигляд підприємства, устаткування, співробітників тощо $[14,17]$. Суб'єктивізм клієнта проявляється в тому, що на сприйняття їм якості обслуговування впливають такі чинники, як чутка про підприємство $з$ надання послуг, попередній досвід клієнта, його потреби, реклама. Тому різні клієнти можуть мати не однакову думку про якість обслуговування певної фірми. Позитивне враження від обслуговування у клієнта залишається в разі, якщо він отримав не менше того, на що розраховував. Для поліпшення транспортного обслуговування інформація про якість транспортних послуг, отримана на підставі накопиченого досвіду і побажань клієнтів, повинна ретельно вивчатися і аналізуватись.

Підвищення якості пасажирських перевезень у системі міського пасажирського транспорту - одне 3 найважливіших напрямків, поставлених перед потребами суспільства у галузі транспорту. Нині оцінку якості транспортних послуг ототожнюють 3 оцінкою рівня транспортного обслуговування пасажирів.

\section{Мета і постановка задачі}

Результати аналізу практичних і наукових літературних джерел свідчать про наявність достатньо великої кількості підходів щодо оцінки якості обслуговування пасажирів, більшість 3 яких грунтується на отриманні достовірної, об'єктивної інформації про pyx T3 на маршруті (натурні обстеження пасажиропотоків). В результаті реалізації яких існує можливість встановити рівень якості транспортних послуг. Так, використання табличного методу обстеження пасажиропотоків дозволяє отримати інформацію про кількість перевезених пасажирів, пасажирооборот зупиночних пунктів, напрямки і потужність пасажиропотоків, ступень використання місткості ТЗ. В свою чергу, використання візуального методу обстеження пасажиропотоків дає можливість оперативно визначити ступень заповнення рухомого складу і потужність пасажиропотоку на найбільш навантажених ділянках маршруту по годинах доби в певні дні тижня.

Отже, метою даної роботи є проведення оцінки якості транспортного обслуговування пасажирів на маршруті №240 м. Одеси на основі результатів натурних спостережень за роботою Т3 та розробка практичних рекомендацій щодо підвищення якості роботи автобусів на маршруті.

\section{Характеристика маршруту}

Для задоволення потреб населення м. Одеси в пасажирських перевезеннях у місті створено мережу автобусних, трамвайних і тролейбусних маршрутів. Загальна довжина маршрутної мережі міста складає 3457,4 км. Щільність автобусної мережі складає

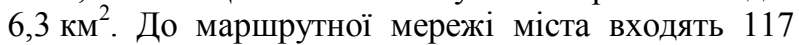
маршрутів, у тому числі: 20 трамвайних, 11 тролейбусних і 86 автобусних маршрутів. На всіх маршрутах електротранспорту, а також на 38 автобусних маршрутах транспорт працює у звичайному режимі руху. Транспорт, що працює у звичайному режимі руху, здійснює перевезення пільгових категорій пасажирів у повному обсязі. На 67 автобусних маршрутах транспорт працює в режимі маршрутного таксі, що перевозять пільгові категорії пасажирів за скороченим переліком [18].

Міський автобусний маршрут загального користування № 240 «вул. Паустовського - вул. Преображенська» (рис. 1) сполучає Суворовський та Приморський райони м. Одеси. Суворовський район поєднує в собі житловий масив «Котовського», рекреаційні та великі промислові зони, коли Приморський район $є$ історичним центром міста, де сконцент- 
ровані масштабний житловий масив із багатоповерховою забудовою, культурно-громадські та адміністративні центри, науково-освітня сфера та портовопромисловий комплекс. Також маршрут поєднує дві великі залізничні станції - «Одеса-Східна» та «Одеса-Головна», що $\epsilon$ великими пасажироутворюючими та пасажиропоглинаючими пунктами.
Маршрут починається 3 вулиці Паустовського, де розташувався ринок Північний, а завершується на вулиці Преображенська, яка межує 3 ринком Приво3, що $є$ великим продовольчим ринком у межах історичного центру міста, та Привокзальною площею. Автобусний маршрут проходить крізь декілька закладів вищої освіти.

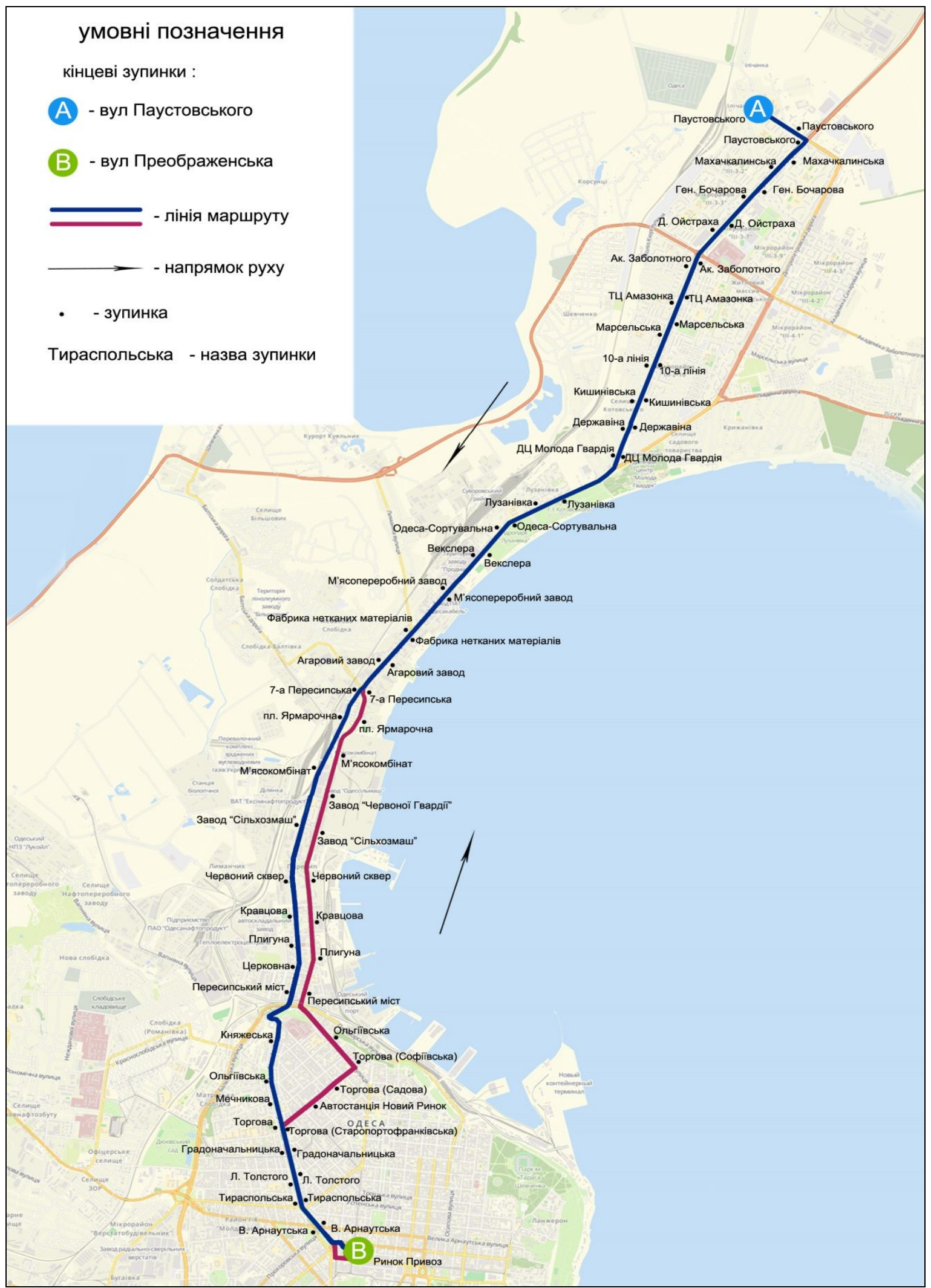

Рис. 1. Схема маршруту № 240 «вул. Паустовського - вул. Преображенська» 
Автобусний маршрут № 240 є радіальним, маятниковим маршрутом. Згідно 3 паспортом маршруту у звичайному режимі руху починає працювати на маршруті з 06:00 (від вул. Паустовського) до 22:00 (на вул. Паустовського). У режимі маршрутного таксі, робота на маршруті починається о 05:20 (від вул. Паустовського), а завершується о 24:00 (на вул. Паустовського). Перевезення здійснюються постійно та щоденно. Розклад руху не змінюється від дня тижня.

Перевезення пасажирів на маршруті № 240 здійснюється приватним акціонерним товариством «Північтранс». Зараз ПАТ «Північтранс» працює в м. Одесі та Одеській області, м. Ізмаїл, м. Кривий Ріг, м. Дніпрі, Київській та Житомирській областях. Підприємство обслуговує 93 міських, 78 приміських та 40 міжміських маршрутів.

На маршруті № 240 «вул. Паустовського - вул. Преображенська» працюють міські автобуси марки А079.52-10 Бориспільського автомобільного заводу.

Згідно з паспортом маршруту, довжина маршруту у прямому напрямку становить - 19,6 км, у зворотному - 20,4 км. Тривалість рейсу у звичайному режимі руху становить в прямому напрямку 56 хв, у зворотному - 57 хв. Тривалість рейсу у режимі руху маршрутного таксі становить 50 хв. у прямому напрямку, та 55 хв. у зворотному. Диспетчерські та контрольні пункти знаходяться на обох кінцевих пунктах маршруту. Також, на вул. Паустовського наявний майданчик для розвороту автобусу. Під час руху, на маршруті зустрічаються такі небезпечні ділянки:

- залізничні переїзди, що не охороняються на вул. Чорноморського козацтва та вул. Отамана Головатого (Суворівський район);

- перетинання 3 трамвайними коліями - вул. Паустовського, Молода Гвардія, 7-а Пересипська, Пересипський міст (Суворівський район) та на вул. Тираспольській, Малій Арнаутській, Преображенський, спуску Марінеско (Приморський район). Також, по вул. Старопортофранківській трамвайні колії розташовані посередині проїзної частини.

Від вул. Преображенської і до зупинки Молода гвардія, автобусний маршрут № 240 дублюється маршрутом № 250 «ринок Привоз- вул. Жоліо-Кюрі», який об’їжджає житловий масив «Котовський» вулицею Семена Палія.

\section{Основний матеріал}

Для проведення оцінки якості транспортного обслуговування пасажирів на маршруті № 240 «вул. Паустовського - вул. Преображенська» в період з 22.10.18 по 28.10.18 включно було проведено обстеження пасажиропотоків візуальним і табличним методами. Для проведення обстеження візуальним методом на маршруті було обрано 3 зупиночних пункти у прямому та зворотному напрямках: зупинка «Академіка Заболотного», «7-а Пересипська» та «Торгова». Обстеження проводились протягом 1 години у трьох часових проміжках в прямому та зворотному напрямках руху: ранок - 7:00 - 8:00; день - 14:00 15:00 та вечір - 17:00 - 18:00.
Результати свідчать, що найбільша ступінь заповнення салону автобуса у ранковий період в прямому напрямку буднів відповідає 5 і 6 балам - у салоні тісно, просвітів майже немає, або ж салон переповнений, посадка пасажирів неможлива. Це зумовлено тим, що велика кількість пасажирів прямують зі спального району до місць навчання та роботи. Ближче до кінця маршруту ступінь заповнення знижується до 4-2 балів - місця для сидіння зайняті, іноді в проходах можуть стояти пасажири, але прохід залишається вільним. Заповнення салону в зворотному напрямку становить від 3 до 1 балу.

Найбільша ступінь заповнення салону у денний період спостерігається у зворотному напрямку будніх днів і відповідає 6-4 балам. Більшістю пасажирів у цей період $є$ студенти ЗВО та коледжів, які повертаються 3 навчання до спального району. Ближче до кінця маршруту ступінь заповнення знижується до 3-2 балів - стоячих пасажирів майже немає. Наповнення салону у прямому напрямку становить 3-2 бали, іноді в салоні є стоячі пасажири, що відповідає оцінці у 4 бали.

Найбільша ступінь заповнення у вечірній період спостерігається у зворотному напрямку будніх днів і відповідає 6-4 балам. Салон автобусу заповнений переважно пасажирами, що повертаються зі своïx робочих місць до спального району міста. Ближче до кінця маршруту, ступінь заповнення знижується до 3-2 балів. Наповнення салону в прямому напрямку становить 3-2 бали. На деяких ділянках маршруту ступінь заповнення салону знижується до 1 бала. У вихідні дні ступінь заповнення салону автобуса відповідає 3-1 балам та розподіляється рівномірно між прямим і зворотнім напрямками руху.

На основі бальної оцінки результатів обстеження пасажиропотоку візуальним методом встановлені значення коефіцієнту статичного використання місткості автобусу. У будні дні ранкового періоду в прямому напрямку на зупиночних пунктах «Ак. Заболотного» та «7-а Пересипська» його значення коливається в межах 1,1-0,9, що свідчить про те, що салон заповнений повністю, при значенні 1,1 посадка пасажирів неможлива, на зупиночних пунктах спостерігаються відмови пасажирам у посадці. На зупинці «Торгова» наповнення салону поступово спадає, значення коефіцієнту статичного використання місткості автобусу знижується до 0,4. У зворотному напрямку будніх днів значення коефіцієнту статичного використання місткості автобусу не перевищує 0,5.

У вихідні дні наповнення салону на зупиночних пунктах розподіляється рівномірно, на зупинках «Ак. Заболотного» та «7-а Пересипська» варіюється від 0,4 до 0,7, на зупинці «Торгова» - від 0,2 до 0,4.

У будні дні денного періоду на зупиночному пункті «Ак. Заболотного» заповнення салону розподіляється рівномірно у всіх напрямках руху, а значення статичного коефіцієнту використання місткості автобусу змінюється від 0,2 до 0,5. На зупинках «7-а Пересипська» та «Торгова» у прямому напрямку руху значення коефіцієнту статичного використання місткості автобусу становить 0,4-0,7, а в зворотному напрямку - 0,7-0,9, іноді 
досягає 1,1. Спостерігаються відмови у посадці пасажирам на зупинці «Торгова».

У вихідні дні наповнення салону на зупиночних пунктах розподіляється так: у суботу, в прямому напрямку руху коефіцієнт статичного використання місткості автобусу варіюється від 0,5 до 0,7 на усіх досліджуваних пунктах, у зворотному напрямку коефіцієнт змінюється від 0,2 до 0,5; у неділю в прямому та зворотному напрямках руку значення коефіцієнту наповнення розподіляється рівномірно між напрямками руху та становить від 0,2 до 0,5.

У будні дні вечірнього періоду у прямому напрямку ступінь заповнення автобуса варіюється в межах від 0,2 до 0,4. На зупиночному пункті «7-а Пересипська» значення коефіцієнту статичного використання місткості автобусу іноді сягає 0,5. У зворотному напрямку на зупинках «Торгова» та «7а Пересипська» значення коефіцієнту статичного використання місткості автобусу сягає від 0,7 до 1,1. Відмов у посадці за досліджуваний період помічено не було. На зупинці «Ак. Заболотного» у зворотному напрямку значення коефіцієнту статичного використання місткості автобусу змінюється в межах від 0,2 до 0,5. У вихідні дні наповнення салону на зупиночних пунктах розподіляється рівномірно - від 0,2 до 0,4 .
Для проведення обстеження табличним методом, згідно з розкладом руху автобусів, було обрано три часові проміжки: ранок: 6:59 - 7:44 (прямий напрямок руху), 7:49 - 8:34 (зворотній напрямок руху); день: 13:35 - 14:20 (прямий напрямок руху), 14:25 - 15:10 (зворотній напрямок руху); вечір: 16:42 - 17:27 (прямий напрямок руху), 17:32 18:17 (зворотній напрямок руху).

На основі отриманих даних обстеження пасажиропотоків табличним методом визначено основну інформацію, яка в подальшому використовується для розрахунку показників оцінки якості транспортного обслуговування пасажирів на маршруті. Приклад такої інформації для ранкового періоду обстеження наведено в табл. 1.

На основі результатів обох обстежень було розраховано значення критеріїв оцінки якості обслуговування пасажирів на маршруті: середню дальність поїздки пасажира, коефіцієнт нерівномірності пасажиропотоків, коефіцієнти статичного та динамічного використання місткості автобусу, коефіцієнт змінності пасажирів, регулярність руху автобусів та час очікування пасажира на зупиночному пункті. Розрахункові значення критеріїв оцінки якості обслуговування пасажирів у ранковий період представлені в табл. 2.

Таблиия 1 - Результати обстеження пасажиропотоків табличним методом в ранковий період

\begin{tabular}{|c|c|c|c|c|c|}
\hline $\begin{array}{l}\text { День } \\
\text { тижня }\end{array}$ & $\begin{array}{c}\text { Напря- } \\
\text { мок } \\
\text { руху } \\
\end{array}$ & $\begin{array}{c}\text { Обсяг переве- } \\
\text { зень, } Q_{p}, \text { пас }\end{array}$ & $\begin{array}{l}\text { Обсяг транспортної } \\
\text { роботи, } W_{p} \text {, пас-км }\end{array}$ & $\begin{array}{l}\text { Потужність паса- } \\
\text { жиропотоку, } F, \text { пас }\end{array}$ & $\begin{array}{c}\text { Середнс значен- } \\
\text { ня пасажиропо- } \\
\text { току, } F_{c e p} \text {, пас } \\
\end{array}$ \\
\hline \multirow{2}{*}{ Понеділок } & прямий & 69 & 694,91 & 1234 & 34,28 \\
\hline & зворотній & 64 & 282,61 & 526 & 14,61 \\
\hline \multirow{2}{*}{ Вівторок } & прямий & 60 & 691,04 & 1233 & 34,25 \\
\hline & зворотній & 54 & 290,83 & 518 & 14,39 \\
\hline \multirow{2}{*}{ Середа } & прямий & 51 & 651,78 & 1154 & 32,06 \\
\hline & зворотній & 49 & 315,87 & 569 & 15,81 \\
\hline \multirow{2}{*}{ Четвер } & прямий & 48 & 671,42 & 1192 & 33,11 \\
\hline & зворотній & 38 & 321,21 & 568 & 15,78 \\
\hline \multirow{2}{*}{ П'ятниця } & прямий & 46 & 650,72 & 1156 & 32,11 \\
\hline & зворотній & 58 & 310,81 & 555 & 15,42 \\
\hline \multirow{2}{*}{ Субота } & прямий & 41 & 430,99 & 773 & 21,47 \\
\hline & зворотній & 47 & 307,4 & 545 & 15,14 \\
\hline \multirow{2}{*}{ Неділя } & прямий & 32 & 320,4 & 568 & 15,78 \\
\hline & зворотній & 41 & 328,38 & 599 & 16,64 \\
\hline
\end{tabular}

Таблиия 1 - Значення критеріїв оцінки якості обслуговування пасажирів у ранковий період

\begin{tabular}{|l|l|c|c|c|c|}
\hline $\begin{array}{c}\text { День } \\
\text { тижня }\end{array}$ & $\begin{array}{c}\text { Напрямок } \\
\text { руху }\end{array}$ & $\begin{array}{c}\text { Середня даль- } \\
\text { ність поїздки, км }\end{array}$ & $\begin{array}{c}\text { Коефіціснт } \\
\text { нерівномірності }\end{array}$ & $\begin{array}{c}\text { Коефіціснт динамічного } \\
\text { використання місткості }\end{array}$ & $\begin{array}{c}\text { Коефіцієнт } \\
\text { змінності }\end{array}$ \\
\hline \multirow{2}{*}{ Понеділок } & прямий & 10,07 & 1,31 & 0,84 & 1,53 \\
\cline { 2 - 6 } & зворотній & 4,42 & 1,44 & 0,33 & 3,05 \\
\hline \multirow{2}{*}{ Вівторок } & прямий & 11,52 & 1,26 & 0,84 & 1,4 \\
\cline { 2 - 6 } & зворотній & 5,39 & 1,81 & 0,34 & 2,08 \\
\hline \multirow{2}{*}{ Середа } & прямий & 12,78 & 1,34 & 0,37 & 2,19 \\
\cline { 2 - 6 } & зворотній & 6,45 & 1,39 & 0,82 & 1,12 \\
\hline \multirow{2}{*}{ Четвер } & прямий & 13,99 & 1,3 & 0,37 & 1,65 \\
\cline { 2 - 6 } & зворотній & 8,45 & 1,46 & 0,79 & 1,12 \\
\hline \multirow{2}{*}{ П'ятниця } & прямий & 14,15 & 1,28 & 0,36 & 1,76 \\
\cline { 2 - 6 } & зворотній & 5,36 & 1,36 & 0,36 & 1,74 \\
\hline \multirow{2}{*}{ Субота } & прямий & 10,51 & 1,26 & 0,39 & 1,39 \\
\cline { 2 - 6 } & зворотній & 6,54 & 1,78 & 0,38 & 2,05 \\
\hline \multirow{2}{*}{ Неділя } & прямий & 10,01 & 1,46 & & \\
\hline
\end{tabular}


За результатами розрахунків можна відзначити, що коефіцієнт динамічного використання місткості автобусу у ранковий період будніх днів в прямому напрямку руху коливається в межах від 0,79 до 0,84 .

У зворотному напрямку значення коефіцієнту динамічного використання місткості є значно меншим, змінюється в межах від 0,32 до 0,37. Це зумовлено коливанням пасажиропотоку за напрямками руху протягом маршруту. Але невелике значення коефіцієнту динамічного використання місткості у зворотному напрямку компенсується більшим значенням коефіцієнту змінності, який показує, скільки пасажирів було перевезено за рейс на одному місці.

У денний період будніх днів значення коефіцієнту динамічного використання місткості становить від 0,63 до 0,68 у зворотному напрямку руху, і $\epsilon$ більшим за аналогічні значення у прямому напрямку руху - від 0,27 до 0,46.

У вечірній період будніх днів значення коефіцієнту динамічного використання місткості становить від 0,68 до 0,75 у зворотному напрямку руху, що також $є$ більшим за аналогічні значення у прямому напрямку руху, яке становить від 0,27 до 0,34 .

Коефіцієнт змінності відповідно більший у прямому напрямку за аналогічний показник у зворотному.

У вихідні дні значення критеріїв оцінки якості розподіляються рівномірно на усіх напрямках руху.

Також за результатами обстежень встановлено той факт, що автобуси протягом тижня рухаються маршрутом 3 регулярністю у 88,09 \%. Недотримання розкладу руху зумовлено втратою часу під час вечірніх заторів.

Розрахунковий час очікування на зупиночному пункті становить 8,25 хв.

\section{Висновки}

Результати аналізу стану проблем оцінювання якості обслуговування пасажирів громадським транспортом показали, що основним завданням для перевізника $є$ забезпечення найбільш можливої високої якості пасажирських перевезень. Вихідними даними для вирішення проблеми якості обслуговування $є$ інформація про особливості формування загальної і транспортної рухливості населення, про розмір пасажиропотоків, їх зміну в просторі і в часі.

На основі результатів натурних спостережень встановлено, що обсяг перевезення у прямому та зворотному напрямках руху приблизно однаковий. Обсяг виконаної транспортної роботи, наповнення салону та середнє наповнення в ранковий період будніх днів більші за аналогічні у зворотному напрямку. У денний період будніх днів обсяг транспортної роботи, наповнення салону та середнє наповнення у зворотному напрямку більші за аналогічні показники у прямому напрямку. У вечірній період будніх днів обсяг транспортної роботи, наповнення салону та середнє наповнення у зворотному напрямку більші за аналогічні показники у прямому напрямку. У вихідні дні ці показники мають приблизно однакові значення у прямому та зворотному напрямках руху.

Максимальна ступінь заповнення салону автобусу спостерігається у прямому напрямку зранку в будні дні, у зворотному напрямку вдень та ввечері. Це зумовлене особливостями транспортної рухливості населення - поїздками вранці зі спальних районів до місць роботи та навчання та поверненням протягом дня назад. У вихідні дні ступінь заповнення салону розподіляється рівномірно протягом усього дня. Для підвищення якості обслуговування пасажирів на маршруті пропонується зменшити інтервал руху автобусів до 9 хв., що призведе до необхідності придбання двох додаткових автобусів місткістю 50-60 пас.

\section{СПИСОК ЛІТЕРАТУРИ}

1. Кучерук Г. Ю. Якість транспортних послуг: управління, розвиток та ефективність: монографія / Г. Ю. Кучерук. Київ: РВЦ ДЕТУТ, 2011. - 208 с.

2. Про автомобільний транспорт. Закон України. [Електронний ресурс] - Режим доступу: http://zakon.rada.gov.ua/laws/show/2344-14.

3. Правила надання послуг пасажирським автомобільним транспортом. [Електронний ресурс] - Режим доступу: http://zakon.rada.gov.ua/laws/show/176-97-п.

4. Про дорожній рух. Закон України. [Електронний ресурс] - Режим доступу: http://zakon.rada.gov.ua/laws/show/3353-12.

5. Правила надання послуг з технічного обслуговування і ремонту колісних транспортних засобів. [Електронний ресурс] - Режим доступу: http://zakon.rada.gov.ua/laws/show/z1609-14\#n16.

6. Положення про робочий час і час відпочинку водіїв автотранспортних засобів. [Електронний ресурс] - Режим доступу: http://zakon.rada.gov.ua/laws/show/z0811-10.

7. Ліцензійні умови провадження господарської діяльності з надання послуг з перевезення пасажирів і вантажів автомобільним транспортом загального користування (крім надання послуг з перевезення пасажирів та їх багажу на такci). [Електронний ресурс] - Режим доступу: https://zakon.rada.gov.ua/laws/show/z0562-10

8. Салухіна Н. Г. Стандартизація та сертифікація товарів і послуг: підруч. / Н. Г. Салухіна, О. М. Язвінська. - К.: Центр учбової літератури, 2010. - $336 \mathrm{c}$.

9. Перелік продукції, що підлягає обов'язковій сертифікації в Україні. [Електронний ресурс] - Режим доступу: http://zakon.rada.gov.ua/laws/show/z0466-05.

10. Правила сертифікації послуг автомобільного транспорту. [Електронний ресурс] - Режим доступу: http://zakon.rada.gov.ua/laws/show/z0192-99.

11. Віниченко В. С. Аналіз факторів і умов, які впливають на якість пасажирських перевезень на міському пасажирському транспорті / В. С. Віниченко, І. Ю. Тарасюк // Коммунальное хозяйство городов. - 2011. - Вип. 99. - С. $369-374$.

12. Валько А. М. Параметральні принципи якості транспортних послуг / А. М. Валько // Наукоємні технології. - 2013. № 3. - C. 317-321. 
13. Тиверовский В. Городской транспорт и его развитие за рубежом / В. Тиверовский // Бюллетень транспортной информации. - 2004. - №7. - С. 31-35.

14. Яновський П. О. Пасажирські перевезення: навч. посібник. / П. О. Яновський. - Київ: НАУ, 2008. - 469 с.

15. Спирин И. В. Организация и управление пассажирскими автомобильными перевозками : учебник для студ. учреждений сред. проф. образования / И. В. Спирин. - М.: Изд-во «Академия», 2003. - 400 с.

16. Худяков В. Исследование оценки качества обслуживания пассажиров городским транспортом в Риге до 2018 года / В. Худяков // Research and technology - step into the future. - 2007. - №2 (2). - C. 5-14.

17. Назаренко Я. Я. Теоретичні аспекти управління якістю перевезень пасажирів автомобільним транспортом. / Я. Я. Назаренко // Управління проектами, системний аналіз і логістика. Технічна серія. - 2013. - Вип. 12. - С. 313-318.

18. Транспорт Одессы. Система мониторинга пассажирского/коммунального транспорта в реальном времени. [Электронный ресурс] - Режим доступа: http://transport.odessa.ua.

Рецензент: д-р техн. наук, проф. О. О. Можаєв, Харківський національний університет внутрішніх справ, Харків Received (Надійшла) 25.04.2019 Accepted for publication (Прийнята до друку) 29.05.2019

\section{Исследование качества обслуживания пассажиров на автобусном маршруте №240 города Одессы}

Е. В. Любый, В. М. Чижик, С. В. Ковбан

Предметом изучения в статье является качество транспортного обслуживания пассажиров на автобусном маршруте №240 в городе Одессе. Целью исследования является проведение оценки качества транспортного обслуживания пассажиров на автобусном маршруте №240 в городе Одессе, основной исходной базой которой являются результаты натурных наблюдений за работой автобусов на маршруте, и выбор мероприятий, направленных на повышение эффективности функционирования маршрута. Задачи исследования: анализ существующих подходов оценки качества транспортного обслуживания пассажиров общественным транспортом; выбор и обоснование подходов изучения спроса на передвижение пассажиров общественным транспортом; разработка методики проведения натурных обследований работы автобусов на маршруте; определение выбранных параметров качества транспортного обслуживания пассажиров; разработка мероприятий по повышению качества транспортного обслуживания пассажиров на маршруте №240. Получены следующие результаты: проанализированы основные подходы оценки качества транспортного обслуживания пассажиров общественным транспортом, а также нормативно-правовую базу в этой сфере; разработана методика и приведены результаты натурных обследований работы автобусов на маршруте; рассчитаны основные параметры качества транспортного обслуживания пассажиров на маршруте (средняя дальность поездки, коэффициент неравномерности пассажиропотоков, коэффициент динамического использования вместимости автобуса, коэффициент сменяемости, транспортную работу, регулярность движения, время ожидания), на основании которых предложены мероприятия по повышению эффективности работы маршрута. Выводы. Разработанная методика проведения натурных обследований качества обслуживания пассажиров дает возможность получить исходные данные для дальнейшего определения и расчета параметров качества обслуживания на маршруте: регулярность движения автобусов, степень использования вместимости транспортного средства, средняя дальность поездки пассажиров, коэффициент сменности, коэффициент неравномерности пассажиропотоков, временя ожидания на остановочном пункте. Для повышения качества обслуживания пассажиров на маршруте предлагается уменьшить интервал движения автобусов до 9 мин., что приведет к необходимости приобретения двух дополнительных автобусов вместимостью 50-60 пасс.

Ключевые слова: общественный транспорт, маршрут, натурные наблюдения, пассажиропоток, качество транспортного обслуживания.

\section{Research of quality of passengers service on the route \#240 of the Odessa city Ye. Liubyi, V. Chizhik, S. Kovban}

Studying subject in the article is quality of transport service of passengers on the bus route № 240 in the Odessa city. The purpose is to assess the quality of transport service of passengers on the bus route № 240 in Odessa city, the main base of which is the results of passenger traffic surveys of buses on the route, and the choice of measures aimed at improving the efficiency of the route. Research problems: analysis of existing approaches to assessing the quality of public transport passenger services; selection and justification of approaches to research the demand for the movement of passengers by public transport; development of methods for conducting passenger traffic surveys of buses on the route; determination of selected parameters of passenger transport service quality; development of measures to improve the quality of transport services for passengers on route № 240. The following results are received: the main approaches to assessing the quality of transport services for passengers by public transport were analyzed, as well as the regulatory framework in this area; a methodology has been developed and the results of passenger traffic surveys of buses on the route are presented; the main parameters of the quality of transport service for passengers on the route were calculated (average trip distance, the coefficient of uneven passenger traffic, the coefficient of dynamic use of the bus capacity, transport work, traffic regularity, waiting time), on the basis of which measures were proposed to improve the efficiency of the route. Conclusions. The developed methodology for carrying out passenger traffic surveys of passenger service quality makes it possible to obtain baseline data for further determining and calculating the parameters of the quality of service on the route: the regularity of buses, the coefficient of use of vehicle capacity, the average trip distance, the shift coefficient, the coefficient of uneven passenger traffic, the waiting time. To improve the quality of passenger service on the route, it is proposed to reduce the interval of buses to 9 minutes, which will lead to the need to purchase two additional buses with a capacity of 50-60 passengers.

Keywords : public transport, route, physical observations, passenger traffic, quality of transport services. 